\title{
CHANGING OVER TO U-100 INSULIN
}

\author{
FRANCOIS BONNICI \\ M Med, FCP(SA). \\ Juvenile Diabetes Clinic, Groote Schuur Hospital
}

\section{OPSOMMING}

'n Nuwe insulienpreparaat met 100 eenhede per milliliter (U-100) word nou in Suid-Afrika bemark. Hierdie sterkte skakel aan by die wêreldwye metriseringstendens en is reeds in sommige lande die enigste insuliensterkte wat toegelaat word.

Die gebruik van hierdie preparaat vergemaklik die selftoediening van insulien vir diabetiese pasiënte aangesien daar minder kans vir doseringsfoute is en 'n kleiner volume van die insulienpreparaat toegedien word. Gesondheidsdienspersoneel word versoek om hulle steun te verleen sodat die geleidelike oorskakeling na die nuwe sterkte glad kan verloop.

\section{Reprinted from the South Afri- can Journal of Hospital Medi- cine. Vol 7 No 11. November 1981. p 208, by kind permis- sion of the author and the Journal, in which it appeared as an editorial.}

A new preparation of insulin containing 100 units per millilitre (U-100) is being introduced in South Africa. Since it was first used in 1922, insulin has been available in at least eight different concentrations but, over the years, only the 40 $\mathrm{U} / \mathrm{ml}$ and $80 \mathrm{U} / \mathrm{ml}$ have been in common usage, the $20 \mathrm{U} / \mathrm{ml}$ having a certain vogue in the United Kingdom only.

The multiplicity of syringes available to diabetics has been one of the main factors creating confusion about dosage. Some of our patients are still using old British Standard syringes with $20 \mathrm{marks} / \mathrm{ml}$ and have to calculate unit doses in terms of syringe divisions, multiplying by 2 or 4 according to the particular insulin strength. The syringes most commonly used have both U-40 and U-80 markings in a staggered fashion on the barrel; this dual scale is visually complicated and distracting. Accidental use of the wrong scale can result in significant dosage error. The recent introduction of syringes with single scale markings and individual colour distinction, has contributed somewhat in simplifying the problem. However, considerable confusion still exists in the minds of diabetic patients, doctors, nurses and pharmacists. Various studies (Joslin, 1974), have shown that from $10 \%$ up to $58 \%$ of patients have a completely erroneous idea of their insulin dosage. Common errors are difficulty with dose calculation, use of the wrong scale on dual-scale syringes, dispensing of the wrong insulin concentration by the pharmacist and mixing of different insulin concentrations in the same syringe.

Most doctors treating diabetic patients are aware that errors in dosage are very common and may lead to loss of metabolic control, hypo-glycaemia or ketoacidosis with serious consequences. It is our responsibility to prevent this from happening, and it will soon be possible for us to do so. The introduction of a new strength of insulin at $100 \mathrm{U} / \mathrm{ml}$ together with a new standard syringe graduated directly in units of insulin will eliminate the present confusion and dosage errors. U-100 is the only insulin strength available in the United States, Canada, Australia, New Zealand and has recently been approved by all professional bodies in the United Kingdom (Bloom et al, 1981). Already most diabetologists in South Africa have expressed their enthusiasm for the principle of $\mathrm{U}-100$ as the sole insulin strength.

$\mathrm{U}-100$ is not a new universal insulin but merely a more concentrated strength of the presently available insulins. It cannot be em- phasised sufficiently that one (1) unit of insulin is exactly the same regardless of the strength. A unit is always constant and it measures a specific amount of activity and is the same for every insulin. If a person injects 35 units of U-40, U-80 or U-100 insulin, the dose delivered is exactly 35 units provided the syringe matches the insulin. The difference is only in concentration.

Converting to the use of U-100 insulin is a logical step in keeping with world-wide trends toward adoption of the metric system. It will simplify matters by reducing both the volume of insulin injected and the chances for errors. Plastic syringes for U-100 will be readily available; if re-used a few times, they are very cheap and safe, (Greenough et al, 1979), and, because of their negligible dead space, they lead to less insulin wastage and more accurate and consistent dosage when insulins of different duration of activity are mixed. For children and patients who require small insulin doses, a U-100 syringe of $0,5 \mathrm{ml}$ capacity accomodating 50 units will be available. This is narrow bored and widely gauged, so that even $1 / 2$ or 1 unit can be measured readilv.

At first glance, it would seem that the decision to introduce a new strength without withdrawing the old ones on the market will be a disadvantage and add to the present confusion. It was argued however, that our country's main centres and 
population being so widely scattered, arbitrary legislation to stop the registration of U-40 and U-80 insulins would have resulted in chaos. It is to be hoped that the medical profession in South Africa - diabetic clinics, physicians, paediatricians and general practitioners - will co-operate in ensuring a smooth changeover to the new insulin strength. Hopefully, also, all insulin manufacturers and importers will follow suit in offering a single insulin strength, and will take the opportunity, when this change is effected, to make available only insulins of higher purity.

A programme for informing and instructing doctors and patients is already underway to ensure that acute problems of gross dosage changes do not arise. Newly diagnosed diabetics should be started immediately on the new insulin strength and it is also wise for all diabetics to convert to the new strength as soon as possible. The changeover is easy as the same number of units are used. However, as the new insulin strength is only marketed in the highly purified monocomponent variety, it is wise, in the case of patients being changed from the old impure insulins, to reduce the total dose by about $20 \%$, thereafter making appropriate adjustments.

Major advances in the management of insulin-requiring diabetics will take place in the near future. It is to be hoped that the large number of insulin preparations will be reduced, that all insulins will be available in highly purified form and in U-100 strength only, together with a new no-dead space syringe. We believe that this uniformity, convenience and economy will ultimately be in the interest of the diabetic patients and increase the safety of their treatment.

\section{REFERENCES}

Bloom, A; Keen H; Watkins P J: A change to 100-unit insulin dosage will reduce errors. British Medical Journal. 283 1981. pp 33-34.

Greenough, A; Cockrott, P M; Bloom A: Disposable sy ringes for insulin injection. British Medical Journal. 1. 1979 pp 1467 - 1468

Joslin, E P The Treatment of diabetes mellitus 1974. Lea and Febiger. Philadelphia. 8th Ed. p. 378

\section{GYNAECOLOGICAL CYTOLOGY A TEXTBOOK AND ATLAS}

\section{Mathilde E. Boon and Mette Lise Tabbers-Boumeester MacMillan, South Africa 1980}

An interesting body of information, clearly set out and well documented. The headings are clear and the information concise and to the point. The diagrams are explicit and easy to follow. The atlas at the back contains good examples of histology, explaining the discussions in the text.

The advances and experiments done in research work on cancer are very enlightening. The chapters on the normal and abnormal cell structure which precede the research, aid the reader a great deal in understanding the research undertaken.

The chapters on diagnostic examinations and techniques, both at a clinical and laboratory level, are very good.

An interesting and useful reference book for tutors teaching nurses gynaecology, but, too involved at the present time to be recommended as a textbook for nurses who have only a limited number of lectures to follow on the subject. I would, however, consider it useful as a reference book in any gynaecological ward and any library where nursing and medical research references are needed.

B.D. Stott

\section{HOSPITAL AND NURSING YEAR- BOOK FOR SOUTHERN AFRICA}

\section{Thomson Publications, Johannesburg (P.O. Box 8308, Johannesburg, 2000)}

This well-known sourcebook which is updated yearly should be available to all nursing and hospital administrators.

The book includes addresses, telephone numbers and many other details regarding administrative bodies; services and facilities; hospitals, nursing homes and clinics; as well as suppliers of all types of hospital equipment and supplies. There is an interesting section on health care statistics as well as a section on the centres offering basic as well as post-basic nursing courses.

This attractive A4-size publication of over 250 pages contains numerous essential facts and figures conveniently in a single comprehensive reference work. 